\title{
VERSOS DORADOS
}

Hombre, ¡librepensador! ¿Crees que eres el único que piensa en este mundo en que la vida se manifiesta en todas las cosas? Tu libertad dispone de todas tus fuerzas, pero el universo ignora todos tus consejos.

Respeta en la bestia a un espíritu agente: cada flor es un alma que florece a la Naturaleza; en el metal reposa un misterio de amor; "todo es sensible", y todo tiene poder sobre ti.

Sé atento, en el ciego muro una mirada te espía, incluso a la materia se aferra un verbo... ¡No le des un uso impío!

A menudo en el oscuro ser habita un Dios escondido; y como ojo que nace cubierto de sus párpados, ¡un espíritu puro crece bajo la corteza de las piedras! 